\title{
Design Thinking Tanggung Jawab Pemerintah dalam Pemenuhan Hak- Hak Warga Negara Inspirasi Hadis Nabi Saw.
}

\author{
Galbani Fadilah \\ Jurusan Studi Agama-Agama, Fakultas Ushuluddin \\ UIN Sunan Gunung Djati Bandung, Indonesia \\ galbanifa@gmail.com
}

\begin{abstract}
This study aims to discuss the inspiration of the Prophet's hadith. regarding government responsibility. This research method is qualitative through literature study and field studies with a design thinking approach. The results and discussion of this research include the roles and responsibilities of the government in fulfilling the basic rights of citizens which inspire the example of the Prophet in the context of his leadership and governance. This research concludes that the hadith of the Prophet Muhammad has inspirational messages in fostering normative values towards rulers in government.
\end{abstract}

Keywords: Design thinking; Government; Hadith.

\begin{abstract}
Abstrak
Penelitian ini bertujuan membahas inspirasi hadis Nabi Saw. mengenai tanggung jawab pemerintah. Metode penelitian ini bersifat kualitatif melalui studi Pustaka dan studi lapangan dengan pendekatan design thinking. Hasil dan pembahasan penelitian ini meliputi peran dan tanggung jawab pemerintah dalam memenuhi hak-hak dasar warga negara inspirasi keteladanan Nabi dalam konteks kepemimpinan dan pemerintahannya. Penelitian ini menyimpulkan bahwa hadis Nabi Saw. memiliki pesan-pesan inspiratif dalam menumbuhkan nilai-nilai normatif terhadap para penguasa di pemerintahan.
\end{abstract}

Kata Kunci: Design thinking, Hadis, Pemerintah

\section{Pendahuluan}

RUU Omnibus Law yang telah disahkan beberapa waktu lalu memberikan dampak buruk terhadap stabilitas sosial di masyarakat (Arham \& Saleh, 2019), ini mungkin disebabkan karena kurangnya transparansi dalam proses pembuatan RUU tersebut sehingga memunculkan banyak persepsi dan interpretasi di tengah masyarakat. 
Sebelum pengesahannya, RUU ini sudah banyak ditolak oleh berbagai kalangan, baik buruh, mahasiswa, dan bahkan oleh para pakar hukum, karena dalam RUU tersebut dianggap mengandung pasal-pasal yang dapat merugikan rakyat. Ini menjunjukan bahwa problem yang dihadapi oleh pemerintah Indonesia sekarang semakin kompleks, khususnya mengenai kemaslahatan dan kebutuhan rakyat.

Pemerintahan yang ideal tentunya ada pada masa kepemimpinan Nabi Muhammad Saw. Ia merupakan manusia yang sempurna dalam segala aspek, termasuk aspek kepemimpinan dan pemerintahan. Oleh karna itu banyak sekali riwayat dan hadits tentang kepemimpinan dan pemerintahannya. Tentunya ini dapat menjadi inspirasi bagi pemerintah dalam melaksanakan kebijakan-kebijakannya (Dahlan, 2018).

Berdasarkan paparan di atas, penulis berusaha menyusun formula penelitian, yaitu rumusan masalah, pertanyaan penelitian, dan tujuan penelitian (Darmalaksana, 2020a). Rumusan masalah penelitian ini adalah, terdapat inspirasi hadis Nabi Saw. mengenai tanggung pemerintahan. Pertanyaan penelitian ini ialah, bagaimana inspirasi hadis Nabi Saw. mengenai tanggung pemerintahan. Tujuan penelitian ini yaitu membahas inspirasi hadis Nabi Saw. mengenai tanggung pemerintahan. Penelitian ini mengambil fokus pada tanggung tawab pemerintah dalam pemenuhan hak-hak warga negara.

\section{Metode Penelitian}

Metode penelitian ini bersifat kualitatif dengan studi pustaka dan studi lapangan (Darmalaksana, 2020b). Sedangkan analisis dalam penelitian ini digunakan pendekatan design thinking (Darmalaksana, 2019). Adapun prosedur pendekatan design thinking (Darmalaksana, 2020c) seperti pada gambar 1 .

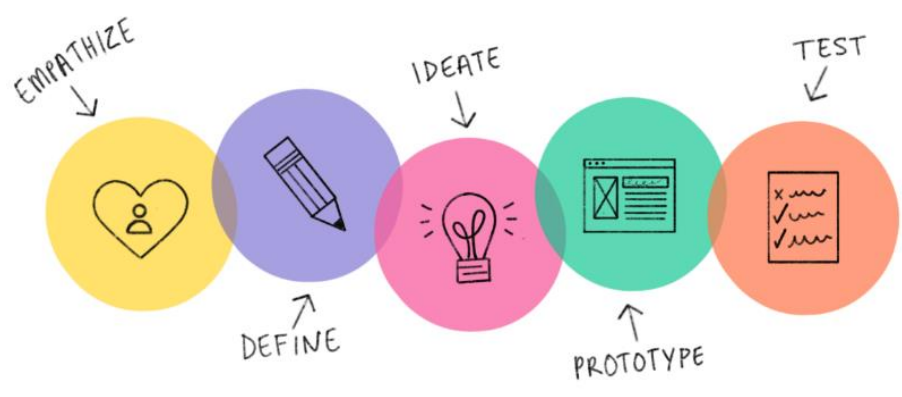

Gambar 1 Prosedur Design Thinking

Prosedur design thinking pada Gambar 1 meliputi fase empathize, define, ideate, prototype, dan test (Henriksen et al., 2017). 
1. Fase empathize (empati) digunakan untuk memahami masalah. Empati dilakukan melalui proses mengamati, keterlibatan melalui percakapan, dan wawancara secara mendalam. Tujuan fase ini adalah memahami masalah secara seksama (Darmalaksana, 2020c; Steinke et al., 2018).

2. Fase define (mendefinisikan) masalah untuk kejelasan masalah. Peneliti menerapkan kekuatan berpikir untuk memahami masalah. Setelah masalah dipahami dengan jelas, peneliti dapat pindah ke tahap berikutnya untuk menghasilkan ide mengatasi masalah. Fase definisi diakhiri dengan ditetapkan secara jelas tentang ruang lingkup masalah (Darmalaksana, 2020c; Steinke et al., 2018).

3. Fase ideate (menghasilkan ide-ide) untuk solusi masalah yang didefinisikan sebelumnya. Peneliti memungkinkan menggunakan logika secara kritis, kreatif, dan inovatif. Fase ideating mencakup peta konsep, kerangka berpikir, dan desain prototipe. Khususnya, prototipe dengan pandangan baru sebagai solusi (Darmalaksana, 2020c; Steinke et al., 2018).

4. Fase prototype (membuat prototipe) dari ide inovasi baru hingga produk terwujud. Semakin realistis ide prototipe, maka semakin baik untuk diwujudkan. Peneliti memungkinkan mengenali kekurangan prototipe untuk desain yang lebih inovatif, sehingga mereka dapat mengulangi pembuatan produk yang lebih baik (Darmalaksana, 2020c; Steinke et al., 2018).

5. Fase test (pengujian) sebagai umpan balik (feedback) terhadap prototipe yang didesain sebelumnya. Pengujian memungkinkan mengulangi proses empati secara lebih diharapkan. Umpan balik dari fase ini akan membantu penyempurnaan prototipe, hingga dipastikan bahwa masalah ditangani dengan tepat (Darmalaksana, 2020c; Steinke et al., 2018).

\section{Hasil dan Pembahasan}

Hasil dan pembahasan melalui pendekatan design thinking di bawah ini.

\section{Hukum dan Hak Warga Negara}

Hukum merupakan subjek negara yang berperan mengatur dan memrintah, bukan manusia (Rosana, 2016). Indonesia adalah negara hukum dan demokrasi, ini dibuktikan dengan adanya prinsip demokrasi serta perlindungan hak asasi manusia dalam pembukaan maupun batang tubuh UUD 1945 (Rosana, 2016). Seperti koin yang memiliki dua sisi, 
prinsip demokrasi memiliki ketergantungan dengan negara hukum, karena demokrasi tidak akan bekerja tanpa negara hukum dan negara hukum tidak akan tegak tanpa adanya demokrasi (Rosana, 2016).

Hukum di Indonesia diatur dalam peraturan perundangan-undangan yang telah disepakati bersama. Pasal-pasal mengenai hak warga negara tercantum pada UUD 1945 pasal 27 sampai dengan 34 (Undang-Undang Dasar Negara Republik Indonesia Tahun 1945, 1945). Umumnya permasalahan mengenai hak warga negara di Indonesia bertumpu pada pasal 27 ayat 2 yang isinya "Tiap warga negara berhak atas pekerjaan dan penghidupan yang layak bagi kemanusiaan," ini dikarenakan tingkat pengangguran dan kesejahteraan rakyat Indonesia masih terbilang minim, hal inilah yang kemudian memunculkan persepsi di tengah masyarakat selaras dengan munculnya kasus-kasus korupsi, kolusi dan nepotisme dalam birokrasi pemerintahan (Juanda Nawawi, 2012).

Seiring berjalannya waktu, permasalahan dan konflik antara pemerintah dengan rakyatnya sendiri semakin kompleks. Mulai dari permasalahan ekonomi, sumber daya alam, hukum, hoax dan lain-lain. Penelitian ini bertujuan untuk memberikan kritik dan saran kepada pemerintah dalam membangun "Good Governance" berdasarkan inspirasi kepemimpinan Nabi Saw yang bertolak dari empati atas hak-hak warga negara yang terbengkalai.

\section{Nabi Saw. dan Hak Warga Negara}

Berbicara soal hak warga negara, Nabi Saw selalu megedepankan dan mengutamakan hak-hak umatnya, baik dari segi kesejahteraan, kebebasan, keadilan, atau bahkan ekonomi (Aji, 2015). Sejak awal berdirinya, Islam telah menunjukan eksistensinya dalam menggelorakan hak-hak asasi manusia, seperti menghapuskan perbudakan, mengakui dan menghormati hak-hak hidup seseorang, serta mengajarkan bahwa setiap orang harus terjamin hak hidup dan kemerdekaannya (Aji, 2015). Prinsip-prinsip hak yang terkandung di ajaran Islam inilah yang kemudian menjadi salah satu poin penting dalam pemerintahan khalifah Islam, khususnya pada masa pemerintahan Nabi Saw.

Nabi Saw pernah bersabda:

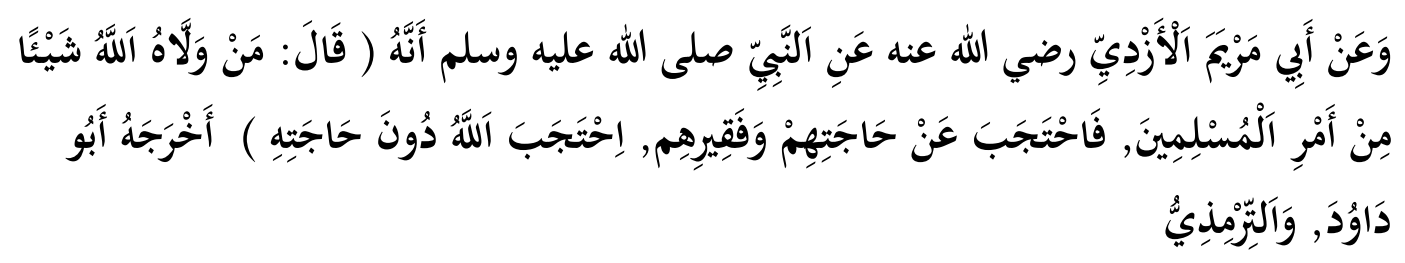

Dari Abu Maryam al-Azdy ra., dari Nabi Saw., beliau bersabda: "Barangsiapa diserahi kekuasaan oleh Allah untuk menangani urusan kaum 
muslimin, namun ia tidak memperhati-kan kebutuhan mereka dan kaum fakir, maka Allah tidak akan memperhatikan kebutuhannya" (HR. Abu Dawud dan Tirmidzi).

Hadits di atas merupakan salah satu bentuk perhatian dan tanggung jawab Nabi terhadap hak-hak umatnya. Selain itu, hadits ini juga meunjukan bahwa para pemilik kekuasaan seharusnya membantu dan memudahkan kebutuhan rakyatnya, khususnya orang lemah.

Nabi memiliki cara dan metodenya sendiri dalam implementasi tanggung jawab, salah satunya yaitu konsep pembangunan ekonomi yang dilakukan oleh Nabi. Contohnya seperti pada sector ekonomi, Nabi mengutamakan perdagangan yang didasari oleh prinsip kejujuran dan keadilan (Saifullah, 2016). Dalam bentuk lain, Nabi juga menanamkan nilai-nilai moralitas agama kepada para pemuda, ini bertujuan agar membangun motivasi dan dorongan dari tiap individu yang berfungsi untuk melahirkan berbagai energi serta potensi yang dapat digunakan saat dibutuhkan (Saifullah, 2016).

Untuk hal kepercayaan (trust) antara Nabi dengan umatnya, Nabi juga menanamkan nilai-nilai moral jujur dan adil yang dijadikan prinsipprinsip dalam membangun ekonomi baik secara sektoral maupun struktural, sehingga memberikan dampak positif berupa kepercayaan yang tinggi antara Nabi dengan umatnya. Cara-cara yang dilakukan Nabi inilah yang kemudian menjadikan ekonomi di masa pemerintahan saat itu maju, sehingga hak-hak umatnya secara ekonomi dapat teratasi.

\section{Good Governance}

Good governance berasal dari istilah Governing yang berarti mempengaruhi atau mengarahkan masalah publik dalam suatu negeri. Good governance juga dapat diartikan sebagai tingkah laku yang didasarkan pada nilai-nilai yang bersifat mengarahkan atau mempengaruhi masalah public, dengan tujuan mewujudkan nilai-nilai tersebut kedalam bingkai paradigma (Juanda Nawawi, 2012).

Pada dasarnya, konsep Good Governance bertujuan untuk memanajemen pembangunan yang solid dan bertanggung jawab selaras dengan prinsip demokrasi dan pasar yang efektif serta efisien, dengan demikian Good Governance tidak terbatas hanya pada ruanglingkup pemerintahan saja, tetapi masyarakat sipil juga dapat turut serta membantu pemerintahan dalam hal demokrasi.

Bertolak dari konsep tersebut, maka kepercayaan sangat penting dalam tata kelola pemerintahan, kepercayaan (trust) baik dalam bentuk sosial maupun politik merupakan syarat mutlak pemerintahan yang baik dan demokratis (Juanda Nawawi, 2012). Hal ini berkaitan erat dengan cara kepemimpinan Nabi, dimana Nabi mengutamakan kepercayaan umat 
khususnya para pemuda yang memiliki potensi besar dalam mengembangkan sumber daya. Kepercayaan umat inilah yang kemudian memudahkan Nabi untuk mengatur pemerintahannya, terutama dalam hal komunikasi. Komunikasi yang baik antara pemimpin dengan umat ini mampu melahirkan sistem tata kelola yang baik juga, sehingga permasalahan-permasalahan di suatu negara dapat terselesaikan secara ideal.

Good Governance merupakan alat penting yang dapat membantu pemerintah dalam menyelesaikan permasalahannya, terutama mengenai hak-hak warga negara. Dimana ada enam prinsip Good Governance yang seharusnya mampu menyelesaikan permasalahan mengenai hak-hak warga negara. Pertama; partisipasi, semua warga negara berhak untuk terlibat dalam membangun pemerintahan yang baik, dengan memberikan pendapat atau kritik yang konstruktif. Kedua; penegakan hukum, bagaimana pemerintah mampu menegakan hukum yang konsisten dan tidak diskriminatif, dimana kasus-kasus yang sering terjadi seperti korupsi dan HAM dapat ditindak secara adil. Ketiga; transparansi, pemerintah harus memiliki transparansi, ini bertujuan untuk membangun kepercayaan antara pemerintah dengan rakyat. Keempat; responsif, pemerintah harus peka terhadap kebutuhan dan keinginan rakyatnya, sehingga menumbuhkan kepecayaan, stabilitas dan integritas. Kelima; kesetaraan dan keadilan, tata kelola pemerintahan yang baik harus berdasar pada pelayanan yang adil setara, sehingga melahirkan kolerasi yang positif antara pemerintah dengan rakyat. Keenam; akuntabilitas, pemerintah harus bertanggung jawab atas kebijakan-kebijakannya, dimana akuntabilitas sebagai syarat dasar untuk mencegah penyalahgunaan kewenangan (Juanda Nawawi, 2012).

Meskipun konsep dan prinsip Good Governance rumit serta sulit untuk dilaksanakan, terutama dalam kehidupan masyarakat yang majemuk seperti di Indonesia, tetapi poin intinya tetap pada kepercayaan. Berkaca dari kepemimpinan Nabi yang menjadikan kepercayaan (trust) umat sebagai aspek penting dalam bernegara, dimana Nabi membangun rasa kepercayaan tersebut dengan memberikan contoh pemerintahan yang baik, jujur, dan adil terhadap umatnya, sehingga tercipta rasa kepercayaan yang tinggi. Pemerintah Indonesia diharapkan mampu untuk membangun kepercayaan rakyat terhadap pemerintah, sehingga tercipta sistem tata kelola yang baik dalam memenuhi hak-hak serta kebutuhan rakyatnya.

\section{Kesimpulan}

Kepemimpinan Nabi Saw. dalam mengatur dan mempimpin pemerintahan memberikan inspirasi bagi umatnya. Bagaimana Nabi menanamkan nilai-nilai moral dan kepercayaan (trust) umat dalam prinsip pemerintahannya, sehingga tercipta tata kelola pemerintahan yang adil dan 
jujur. Selaras dengan kepemimpinan Nabi, prinsip-prinsip Good Governance juga bertumpu pada kepercayaan (trust) rakyat, yang memudahkan komunikasi antara pemerintah dengan rakyat sehingga pemerintah dapat lebih peka terhadap hak-hak warga negara. Penelitian ini diharapkan bermanfaat bagi pembaca. Penelitian ini memiliki keterbatasan literature sehingga dibutuhkan penelitian lebih lanjut dengan literature yang lebih lengkap. Penelitian ini merekomendasikan konsep Good Governance yang bertumpu pada kepercayaan (trust) rakyat untuk diterapkan kedalam sistem pemerintahan di Indonesia.

\section{Referensi}

Aji, A. M. (2015). Hak dan Kewajiban Asasi Manusia Dalam Perspektif Islam. SALAM: Jurnal Sosial Dan Budaya Syar-I, 2(2).

Arham, S., \& Saleh, A. (2019). Omnibus Law dalam Perspektif Hukum Indonesia. PETITUM, 7(2), 72-81.

Dahlan, M. (2018). NABI MUHAMMAD SAW. (Pemimpin Agama dan Kepala Pemerintahan). Rihlah Jurnal Sejarah Dan Kebudayaan, 6(2), 184. https:/ / doi.org/10.24252/ rihlah.v6i2.6912

Darmalaksana, W. (2019). Paper Template Design Thinking Methods for Learning Hadith. Fakultas Ushuluddin UIN Bandung.

Darmalaksana, W. (2020a). Formula Penelitian Pengalaman Kelas Menulis. Jurnal Kelas Menulis UIN Sunan Gunung Djati Bandung.

Darmalaksana, W. (2020b). Metode Penelitian Kualitatif Studi Pustaka dan Studi Lapangan. Pre-Print Digital Library UIN Sunan Gunung Djati Bandung.

Darmalaksana, W. (2020c). Template Penulisan Artikel Hadis dengan Pendekatan Design Thinking. Pre-Prin Digital Library UIN Sunan Gunung Djati Bandung, 1(1), 1-7.

Henriksen, D., Richardson, C., \& Mehta, R. (2017). Design thinking: A creative approach to educational problems of practice. Thinking Skills and Creativity, 26, 140-153. https:/ / doi.org/10.1016/j.tsc.2017.10.001

Juanda Nawawi. (2012). Membangun Kepercayaan Dalam Mewujudkan Good Governance. Jurnal Ilmiah Ilmu Pemerintahan, 3(1), 19.

Undang-Undang Dasar Negara Republik Indonesia Tahun 1945, (1945) (testimony of Presiden Republik Indonesia). https:/ / doi.org/10.1007/s13398-014-0173-7.2

Rosana, E. (2016). Negara demokrasi dan hak asasi manusia. Jurnal TAPIs, 12(1), 37-53.

Saifullah, E. (2016). Pembangunan Ekonomi pada Masa Pemerintahan Rasulullah Saw. Jurnal Pemikiran Dan Pengembangan Perbankan Syariah, 1(2), 77-88.

Steinke, G. H., Al-Deen, M. S., \& LaBrie, R. C. (2018). Innovating 
Jurnal Penelitian Ilmu Ushuluddin Vol. 1 No. 1 (Januari 2021): 15-22 DOI: 10.15575/jpiu.v1.i.11055

information system development methodologies with design thinking. Proceedings of the 5th Conference in Innovations in IT. 